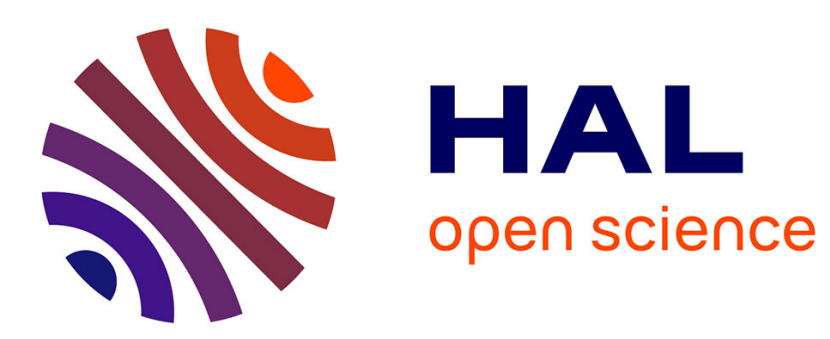

\title{
Efficient Storage of Images onto DNA Using Vector Quantization
}

\author{
Melpomeni Dimopoulou, Marc Antonini
}

\section{To cite this version:}

Melpomeni Dimopoulou, Marc Antonini. Efficient Storage of Images onto DNA Using Vector Quantization. Data Compression Conference (DCC) 2020, Mar 2020, Utah, United States. 10.1109/DCC47342.2020.00085 . hal-02549709

\section{HAL Id: hal-02549709 \\ https://hal.science/hal-02549709}

Submitted on 21 Apr 2020

HAL is a multi-disciplinary open access archive for the deposit and dissemination of scientific research documents, whether they are published or not. The documents may come from teaching and research institutions in France or abroad, or from public or private research centers.
L'archive ouverte pluridisciplinaire HAL, est destinée au dépôt et à la diffusion de documents scientifiques de niveau recherche, publiés ou non, émanant des établissements d'enseignement et de recherche français ou étrangers, des laboratoires publics ou privés. 
Melpomeni Dimopoulou

dimopoulou@i3s.unice.fr

Marc Antonini

Labratoire I3S, Université Côte d'Azur, CNRS

\section{THE PROBLEM:}

- Conventional storage devices can endure for 5-10 years

- $80 \%$ of data is cold (very rarely accessed)

- High cost of reliable storage

THE SOLUTION: Use of DNA as a means of digital data

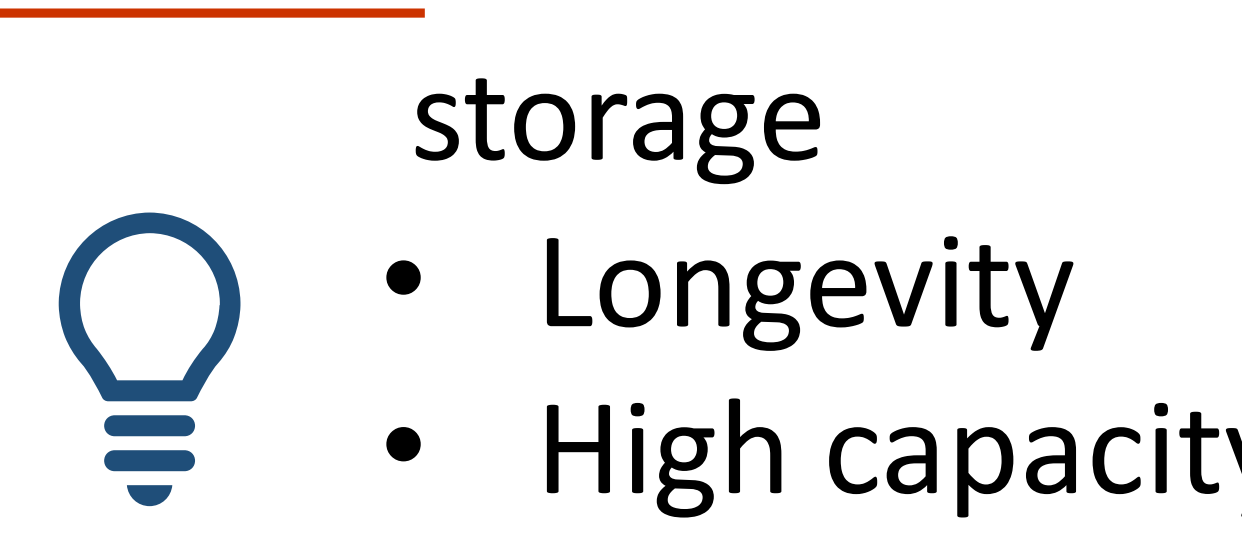

$\rightarrow$ Need for efficient encoding to control the cost of DNA synthesis!

\section{PURPOSE OF THIS WORK:}

- To propose a new efficient method for the encoding of images into DNA using Vector quantization (VQ) improving the results obtained in our previous work $^{* *}$ while controlling the DNA synthesis cost.

THE PROPOSED METHOD:

- DWT decomposition to reduce spatial redundancy

- VQ to encode each DWT

subband

- Closed loop source allocation to optimally compress an image

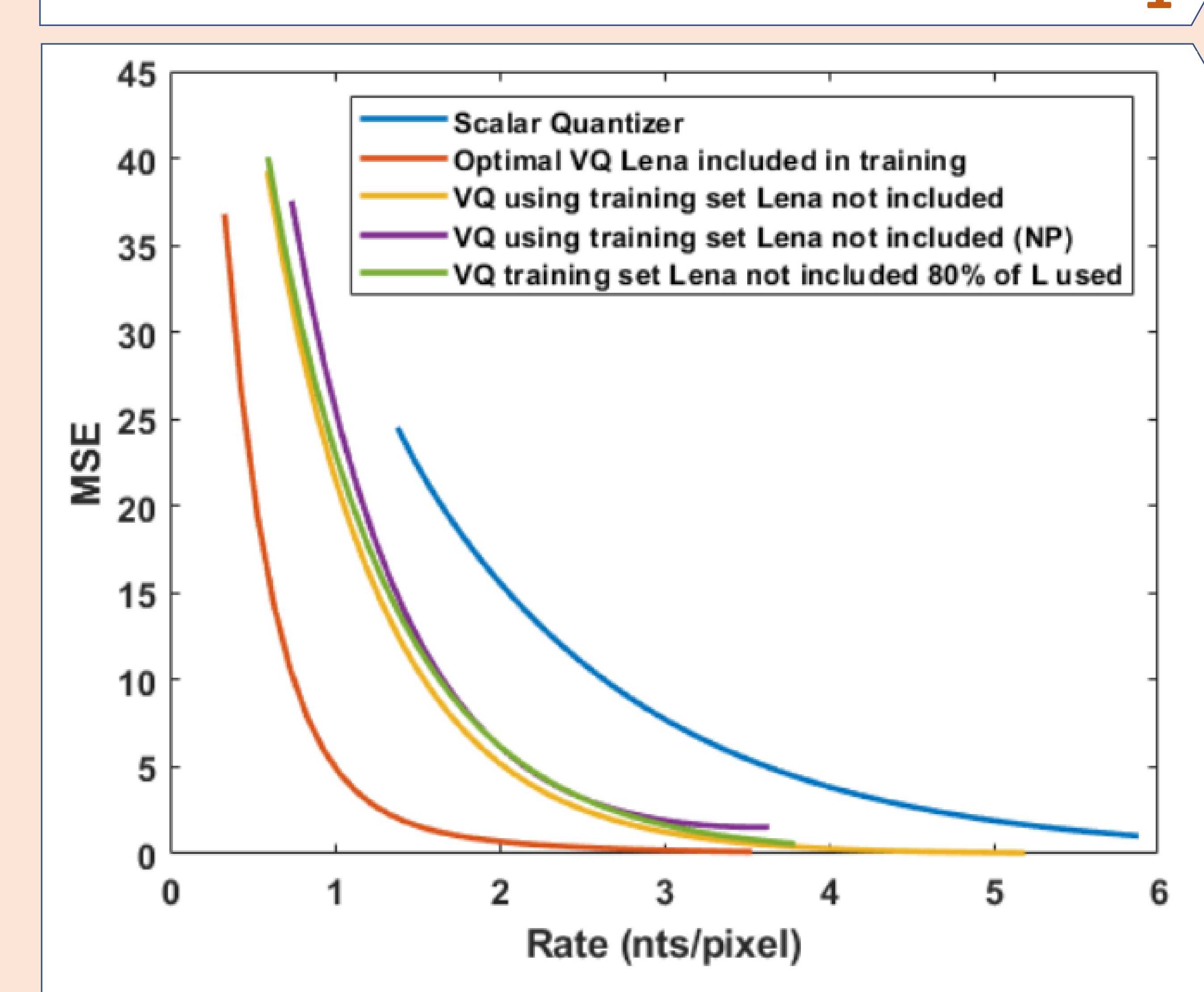

\section{EXPERIMENTAL RESULTS:}

- Image: Lena 512x512

- Training set of different face images to obtain the vectors

- NP: No Patterns $\rightarrow L=2 K$

- $80 \%$ of $\mathrm{L}$ used: $\mathrm{K}=80 \% \mathrm{~L}$

- Results using VQ show great improvement compared to the results obtained in our previous work

** Dimopoulou, Melpomeni, et al. "A biologically constrained encoding solution for long-term storage of images onto synthetic DNA." 2019 27th European Signal Processing Conference (EUSIPCO). IEEE, 2019.

\section{1}

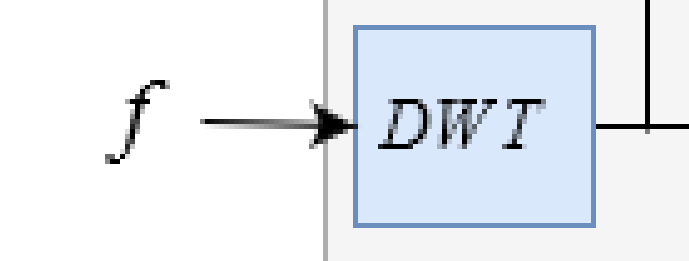

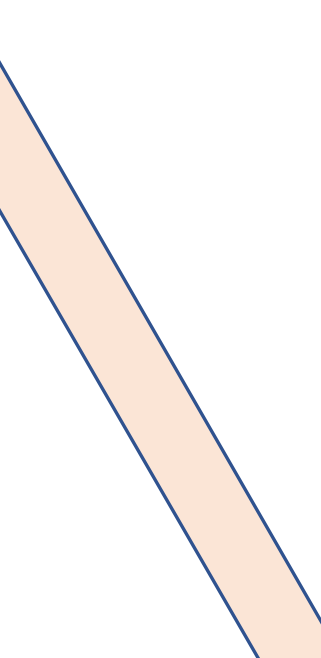

6

\section{NUCLEOTIDE ALLOCATION:}

Goal:

For a desired rate $R_{t}$, find optimal values of $k$ (number of vectors) and $n$ (length of vectors) for VQ that minimizes the distortion.

For each DWT subband:

- Build Rate-Distortion curve for different $k$ and $n$

- Optimal points are lying on the convex hull
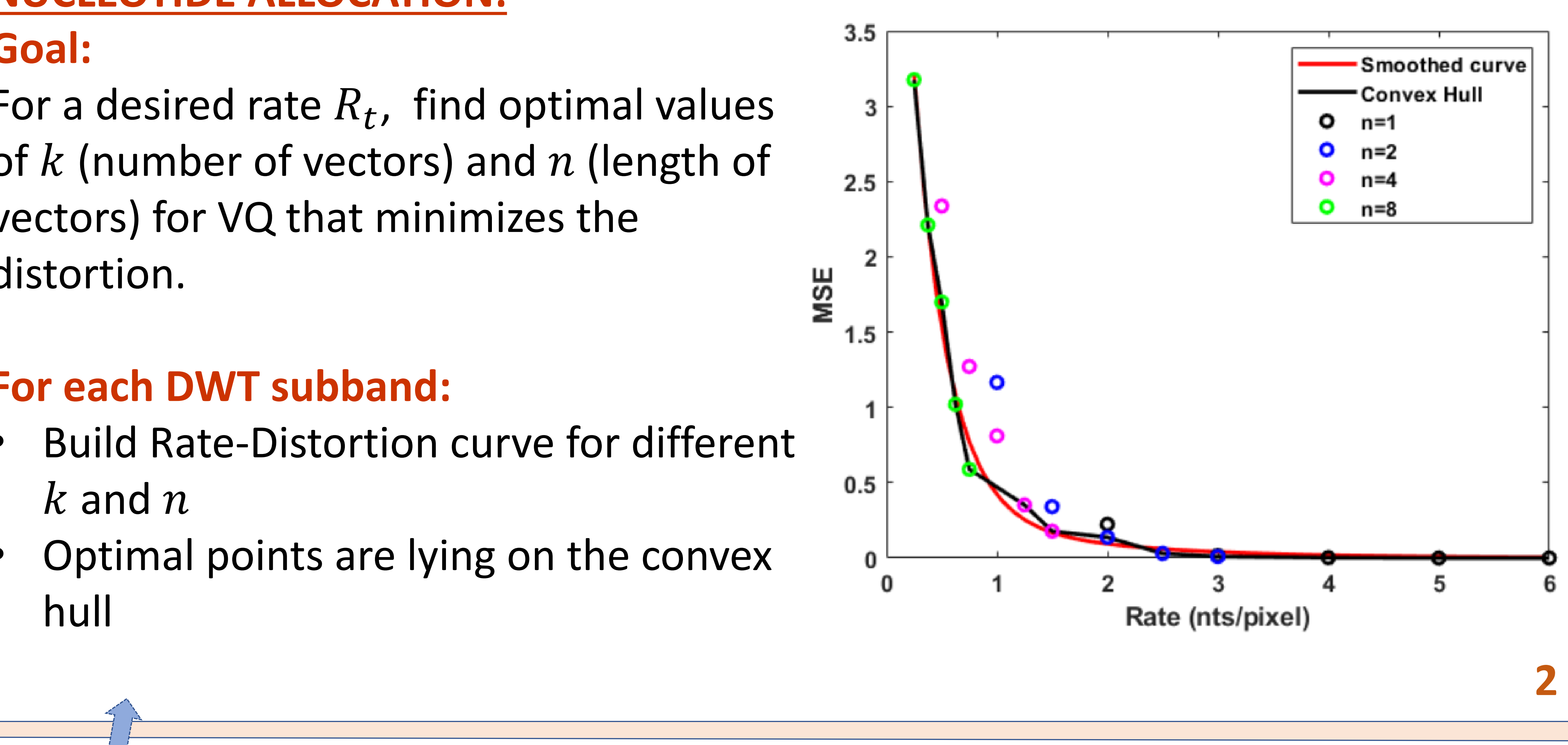

$\sqrt{\substack{\text { Biologid } \\ \text { procodid }}}$

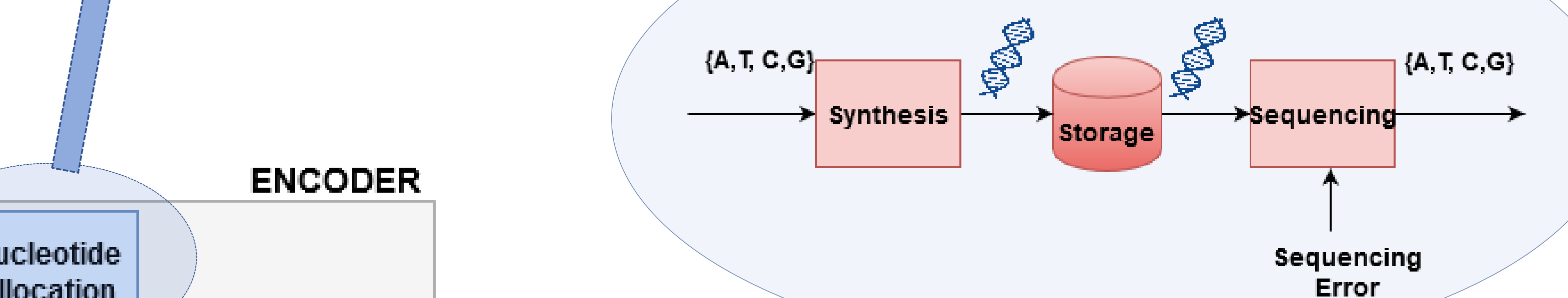

$\rightarrow$ 桠cleotidide

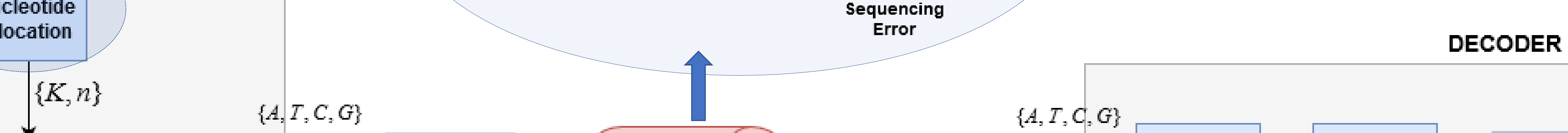

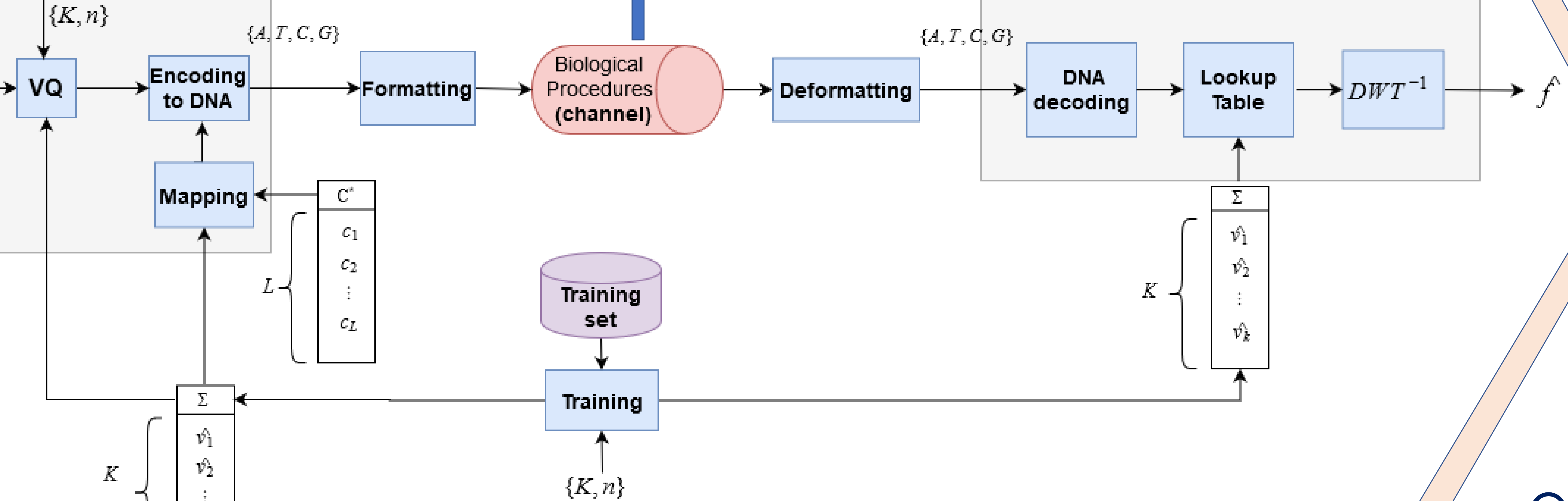

5' ATGT ATAT ATAT ATAT ATGT ATGT GTGT GTAT ATAT ATAT GTGT ATGT ATGT ATAT ACAT ATGT GTAT ATGT 3 ' 5' TGAAG TTGAA GCATA TGATG ACTCT GATCG AGCTC GTCGG TGCTT TGACT CTGAA TAAGC CTTCT TATAG 3 '

Example of an oligo where $\mathrm{k}=\mathrm{L}$ (top oligo) and an oligo were $\mathrm{L}=2 \mathrm{~K}$ (bottom oligo).

The two ways for treating patterns. (1) on the left and (2) on the right

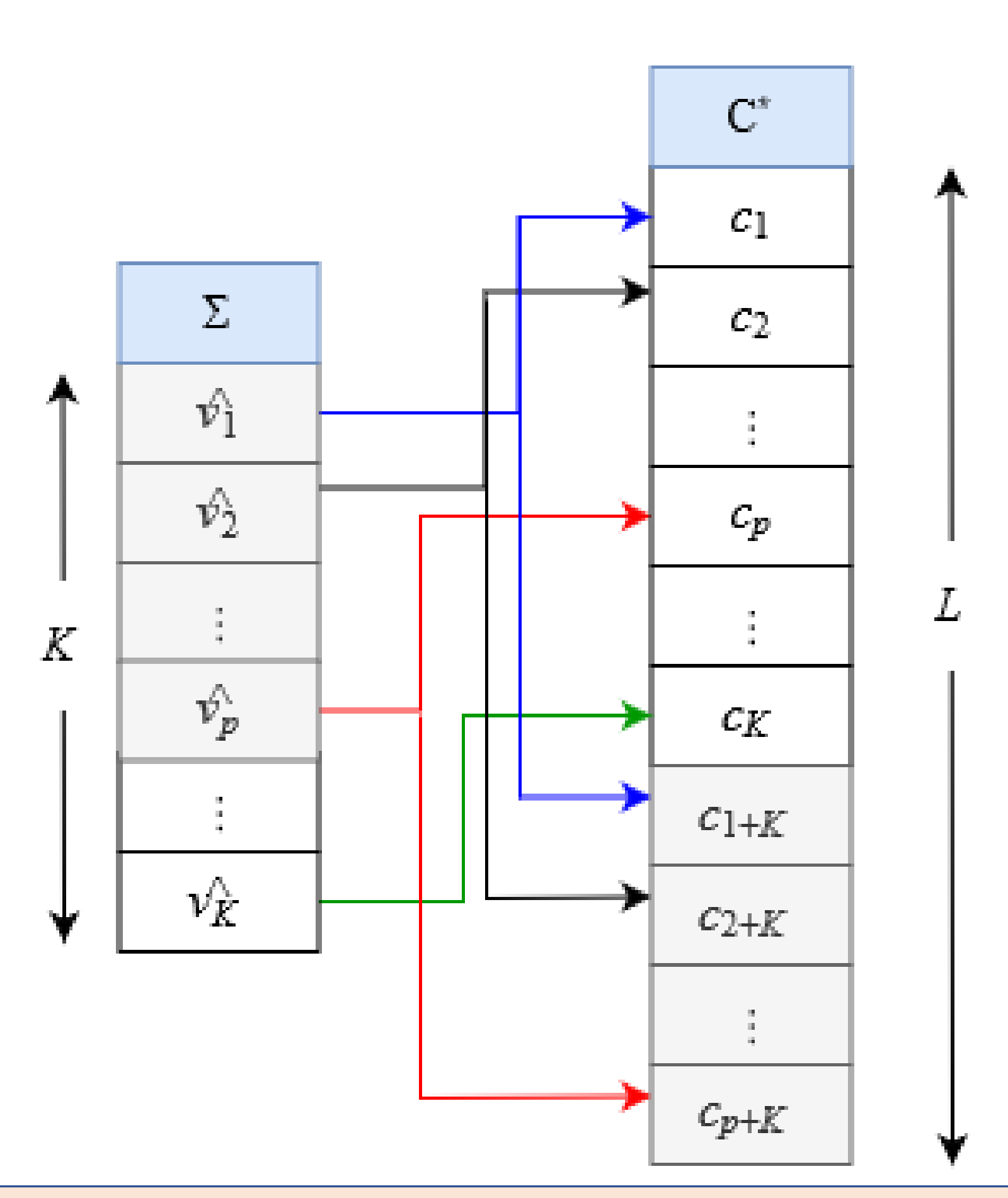

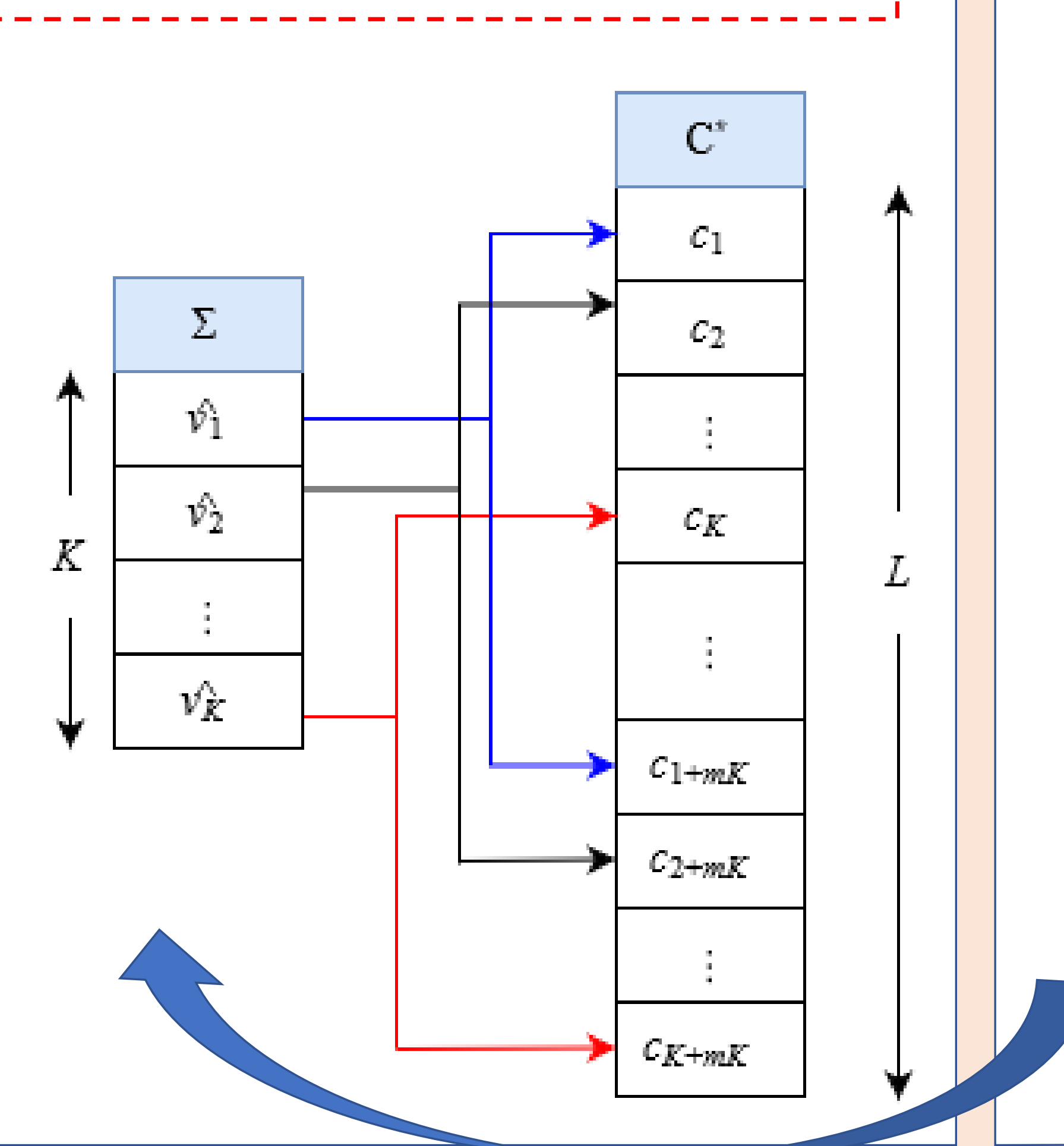

Data Compression Conference

BIOLOGICAL CONSTRAINTS ON THE ENCODING:

Reduction of sequencing error

1) No homopolymers

2) $\% G, C \leq \% A, T$

3) No repetition of short patterns

$\cong$ BUILDING A RESTRICTED QUATERNARY CODE:

Two dictionaries of pair elements:

- $C_{1}=\{A T, A C, A G, T A, T C, T G, C A, C T, G A, G T\}$

$\rightarrow n$ picks: $L=10^{n}$ codewords of length $I=n * 2$

- $C_{2}=\{A, T, C, G\}$

$\rightarrow$ adding a symbol from $C_{2}$ at the end of codewords: $L=10^{n} * 4$

$>$ Codewords of an even length $l$ are built by picking $n=l / 2$ pair-elements from $C_{1}$

$>$ Codewords of odd length $l$ codewords are built by picking $n=(l-1) / 2$ pair-elements from $C_{1}$ and adding a pair element from $C_{2}$ at the end

PATTERN REPETITIONS:

- VQ: efficient for compression

- More subband coefficients will be represented by the same vector

- Neighboring coefficients will be encoded to the same codeword $\rightarrow$ pattern repetitions!

\section{@ Solution:}

Increase code size $L$ to allow double representation

\section{MAPPING:}

To avoid patterns we need: $L \geq K$

Mapping $\Gamma: \Sigma \rightarrow C^{*}$

$m=\lfloor L / K\rfloor$

$\Gamma\left(\hat{x}^{i}\right)=C^{*}(i+\operatorname{rand}(0, m-1) * K)$

Two ways to treat pattern repetition:

1) If $\mathrm{K}<L \leq 2 \mathrm{~K}$ : double representation of most frequent symbols, $m=1$ (left image)

2) If $L \geq 2 K$ : double representation of every word, $\mathrm{m}=2$ (right image) 